\title{
STATISTICAL ANALYSIS OF THE IMPACT OF CLUSTERS ON CARIES PREVALENCE AND INTENSITY IN CHILDREN AGED 6-7 WITH DIFFERENT SOMATIC HEALTH STATUSES
}

DOI: 10.36740/WLek202003104

\author{
Oksana V. Klitynska' ${ }^{1}$ Andriy V. Stishkovskyy ${ }^{2}$, Natalia V. Hasiuk ${ }^{3}$, David S. Avetikov ${ }^{4}$, Viktoria Z. Ivaskevych ${ }^{5}$ \\ 'DEPARTMENT OF PAEDIATRIC DENTISTRY, STATE HIGHER EDUCATIONAL ESTABLISHMENT UZHHOROD NATIONAL UNIVERSITY, UZHHOROD, UKRAINE \\ 2FACULTY OF DENTISTRY, STATE HIGHER EDUCATIONAL ESTABLISHMENT UZHHOROD NATIONAL UNIVERSITY, UZHHOROD, UKRAINE \\ ${ }^{3}$ DEPARTMENT OF THERAPEUTIC DENTISTRY, HORBACHEVSKY TERNOPIL STATE MEDICAL UNIVERSITY, TERNOPIL, UKRAINE \\ ${ }^{4}$ DEPARTMENT OF SURGICAL STOMATOLOGY AND MAXILLOFACIAL SURGERY WITH PLASTIC AND RECONSTRUCTIVE SURGERY OF HEAD AND NECK, \\ UKRAINIAN MEDICAL STOMATOLOGICAL ACADEMY, POLTAVA, UKRAINE \\ 5DEPARTMENT OF PAEDIATRIC DENTISTRY, STATE HIGHER EDUCATIONAL ESTABLISHMENT UZHHOROD NATIONAL UNIVERSITY, UZHHOROD, UKRAINE
}

\begin{abstract}
The aim: Determining the influence of cluster factors on the emergence and progression of caries in first- and second-grade children is appropriate in terms of determining the most significant ones.

Materials and methods: The dental status of 73 children, residents of Uzhhorod, who study in the first grades of secondary schools, has been assessed, three groups have been singled (the control group 26 healthy children). The indices of essential micro- and macronutrients in the hair, saliva, serum and urine, as well as anxiety level have been determined and the statistical analysis has been performed.

Results: Decreased magnesium and calcium content in hair, serum, urine and mouth fluid, iodine is absent. Children of the third group have high levels of anxiety ( $80 \%)$, high rates of caries $(14,8)$ and significantly reduced levels of magnesium relative to normal.

Conclusions: In the patients of the main groups, a direct correlation was found between the presence of somatic pathology and the level of anxiety. In $80 \%$ of children of the third group (CSPS $\geq 3$ ) the level of anxiety is high In the main group patients, a direct correlation was found between the presence of somatic pathology, the level of anxiety, and the decrease in magnesium; The intensity of caries only interacts with a high level of anxiety (1.00), that is, in children who are in constant stress, the intensity of caries increases.
\end{abstract}

KEY WORDS: children, younger school age, anxiety level, biogeochemical deficiency of fluorine and iodine, caries prevalence and intensity

Wiad Lek. 2020;73(3):434-440

\section{INTRODUCTION}

The high prevalence of permanent tooth caries in children in Ukraine [1-3] raises the problem of prevention as the main one in paediatric dentistry. Due to the fact that teeth are most vulnerable to caries after their eruption $[4,5]$, it is especially important to find new approaches to creating programs for the prevention of permanent caries, especially at the stage of immature enamel [6].

Since the eruption of the first permanent molars and the state of incomplete mineralization coincides with a period of increased exposure to stress from the adaptation of the child's organism to school, which reduces nonspecific resistance of the body, carrying out preventive measures during this period significantly reduces the likelihood of carious lesions.

The occurrence of caries is largely determined by the environmental conditions in which the child lives, namely biogeochemical deficiency of trace elements (especially fluorine, iodine, calcium, magnesium, etc.). Such natural zones include the Transcarpathian region as a natural environment in which a person lives [1]. The prevalence of permanent tooth decay in 12-year-old children in this natural zone constitutes $91.4 \pm 2.3 \%$ at an intensity of $11.3 \pm 0.1[7,8]$.

\section{THE AIM}

To establish the correlation between different parameters of micro- and macro elements content in saliva, urine and hair, anxiety level and caries incidence rates in children aged 6-7 with different somatic health status.

\section{MATERIALS AND METHODS}

The dental status of 73 children, residents of Uzhhorod, who study in the first grades of secondary schools, was assessed. Three groups were singled out depending on the coefficient of severity of the general somatic pathology. The control 
Table I. Indicators of anxiety levels, microelements level in oral fluid, hair, serum and urine in children with different prevalence percentage of caries

\begin{tabular}{|c|c|c|c|c|}
\hline $\begin{array}{l}\text { Clinical groups } \\
\text { Indicators }\end{array}$ & $\begin{array}{r}\text { Group } 1 \\
(\mathbf{n}=\mathbf{2 8})\end{array}$ & $\begin{array}{l}\text { Group } 2 \\
(n=25)\end{array}$ & $\begin{array}{l}\text { Group } 3 \\
(n=20)\end{array}$ & $\begin{array}{l}\text { Control group } \\
(n=26)\end{array}$ \\
\hline \multicolumn{5}{|c|}{ Anxiety level } \\
\hline High anxiety level $\mathrm{Al}>50 \%$, & $8,34 \pm 0,48^{*}$ & $39,25 \pm 1,82^{*}$ & $84,20 \pm 2,34^{*}$ & - \\
\hline Medium anxiety level from $20>\mathrm{Al}<50 \%$ & $26,80 \pm 0,95^{*}$ & $45,65 \pm 1,02^{*}$ & $13,50 \pm 0,20^{*}$ & $4,70 \pm 0,01$ \\
\hline Low anxiety level $\mathrm{Al}<20 \%$ & $64,86 \pm 1,76$ & $15,10 \pm 0,45^{*}$ & $2,30 \pm 0,12^{*}$ & $95,30 \pm 1,35$ \\
\hline \multicolumn{5}{|c|}{ The level of microelements in the hair } \\
\hline & & & & norm \\
\hline Ca (Calcium) & $310 \pm 16,02$ & $250 \pm 15,12$ & $140 \pm 16,30 * \circ$ & $300,00-700,00$ \\
\hline Zn (Zinc) & $125 \pm 10,03$ & $110 \pm 8,01^{*}$ & $86 \pm 7,37 * 0$ & $120,00-200,00$ \\
\hline K (Kalium, potassium) & $100 \pm 8,56$ & $140 \pm 7,45$ & $170 \pm 8,21$ & $70,00-170,00$ \\
\hline Mg (Magnesium) & $24,00 \pm 0,21$ & $20,00 \pm 0,48^{*}$ & $14,00 \pm 0,16 * 0$ & $25,00-50,00$ \\
\hline I (lodine) & $0,1^{*}$ & $0,0^{*}$ & $0,0 * 0$ & $0,40-4,00$ \\
\hline Fe (Ferrum, Iron) & $23,0 \pm 0,61$ & $27,0 \pm 0,56$ & $33,0 \pm 1,45$ & $6,00-35,00$ \\
\hline Cu (Cuprum) & $7,20 \pm 0,08$ & $5,60 \pm 0,01 *$ & $4,30 \pm 0,08 * 0$ & $9,00-30,00$ \\
\hline Se (Selenium) & $0,20 \pm 0,01^{*}$ & $0,16 \pm 0,08^{*}$ & $0,13 \pm 0,04^{*} \circ$ & $0,30-1,20$ \\
\hline Mn (Manganese) & $0,27 \pm 0,01^{*}$ & $0,17 \pm 0,07^{*}$ & $0,0 \pm 0,0 * \circ$ & $0,50-2,00$ \\
\hline $\mathrm{Cr}$ (Chrome) & $0,27 \pm 0,05^{*}$ & $0,18 \pm 0,03^{*}$ & $0,12 \pm 0,05 * \circ$ & $0,50-5,00$ \\
\hline \multicolumn{5}{|c|}{ The level of microelements in the serum } \\
\hline $\mathrm{Mg}, \mathrm{mmol} / \mathrm{L}$ & $1,01 \pm 0,1$ & $0,45 \pm 0,05^{*}$ & $0,31 \pm 0,05^{*}$ & $0,70-1,15$ \\
\hline $\mathrm{Ca}, \mathrm{mmol} / \mathrm{L}$ & $2,36 \pm 0,02$ & $2,01 \pm 0,01$ & $1,84 \pm 0,02^{*}$ & $2,25-2,60$ \\
\hline $\mathrm{Ph} \mathrm{mmol} / \mathrm{L}$ & $1,60 \pm 0,11$ & $1,30 \pm 0,13$ & $1,10 \pm 0,09^{*}$ & $1,45-1,77$ \\
\hline $\mathrm{Zn}, \mathrm{mcmol} / \mathrm{L}$ & $16,21 \pm 1,34$ & $9,71 \pm 0,54$ & $8,95 \pm 0,46$ & $9,18-18,36$ \\
\hline $\mathrm{Fe}, \mathrm{mcmol} / \mathrm{L}$ & $16,20 \pm 1,27$ & $11,01 \pm 1,61$ & $9,56 \pm 1,42$ & $10,74-30,08$ \\
\hline $\mathrm{Cu}, \mathrm{mcmol} / \mathrm{L}$ & $20,53 \pm 2,19$ & $10,12 \pm 1,32$ & $9,27 \pm 1,21$ & $11,02-24,39$ \\
\hline $\mathrm{Se}, \mathrm{mcmol} / \mathrm{L}$ & $1,62 \pm 0,04$ & $0,45 \pm 0,05$ & $0,38 \pm 0,13^{*}$ & $0,58-1,77$ \\
\hline \multicolumn{5}{|c|}{ Excretion level of microelements in urine } \\
\hline Mg in urine, $\mathrm{mmol} / \mathrm{L}$ & $0,84 \pm 0,01^{*}$ & $0,76 \pm 0,03^{*}$ & $0,73 \pm 0,03^{*}$ & $0,97 \pm 0,03$ \\
\hline Ca in urine, $\mathrm{mg} /$ day & $188,2 \pm 18,3$ & $195,6 \pm 14,1$ & $201,7 \pm 16,5$ & $183,2 \pm 23,1$ \\
\hline $\mathrm{Ph}$, in urine g / day & $0,94 \pm 0,10 *$ & $1,03 \pm 0,16^{*}$ & $1,37 \pm 0,15^{*}$ & $0,88 \pm 0,10$ \\
\hline \multicolumn{5}{|c|}{ The level of microelements in the oral fluid } \\
\hline $\mathrm{Mg} \mathrm{mmol} / \mathrm{L}$ & $0,06 \pm 0,01$ & $0,03 \pm 0,01$ & $0,01 \pm 0,01$ & $0,08-0,53$ \\
\hline Ca tot., $\mathrm{mmol} / \mathrm{L}$ & $1,31 \pm 0,12$ & $2,41 \pm 0,03$ & $2,89 \pm 0,04$ & $1,28 \pm 0,12$ \\
\hline Ca ion., mmol/L & $1,08 \pm 0,05$ & $1,39 \pm 0,09$ & $1,98 \pm 0,09^{*}$ & $0,94 \pm 0,05$ \\
\hline $\mathrm{P}, \mathrm{mmol} / \mathrm{L}$ & $5,91 \pm 0,31$ & $5,13 \pm 0,11$ & $5,56 \pm 0,21$ & $6,09 \pm 0,37$ \\
\hline Alkaline phosphatase, activity unit & $26,61 \pm 1,02$ & $44,04 \pm 0,81^{*}$ & $51,43 \pm 1,98^{*}$ & $21,48 \pm 1,02$ \\
\hline \multicolumn{5}{|c|}{ Caries prevalence and intensity } \\
\hline Caries prevalence & $88,6 \pm 5,60^{*}$ & $93,2 \pm 3,80^{*}$ & $96,4 \pm 1,98^{*}$ & $65,3 \pm 2,89$ \\
\hline Caries intensity (cf+CFE) & $5,3 \pm 0,20$ & $8,6 \pm 0,23^{*}$ & $14,8 \pm 0,18^{*}$ & $4,1 \pm 0,23$ \\
\hline
\end{tabular}

Note: ${ }^{*}$ - significance of differences between indicators of a conditional norm or control group $(p<0.05)$.

${ }^{0}$ - significance of differences between the first and third groups $(p<0.05)$.

comparison group consisted of 26 children of the same age, residents of Uzhhorod free from caries, i.e. healthy children.

The examination and treatment of children were carried out in the dental offices of the clinical base of the Department of Paediatric Dentistry at the Higher Educational Institution "Uzhhorod National University" in Uzhhorod
Municipal Children's Outpatient Clinic. All the children attended secondary schools. The work began after the children's parents or guardians had given their informed consent to participate in the study.

In the surveyed children in the clinical groups, the following indicators were analyzed: caries intensity (cf + CFE index) 


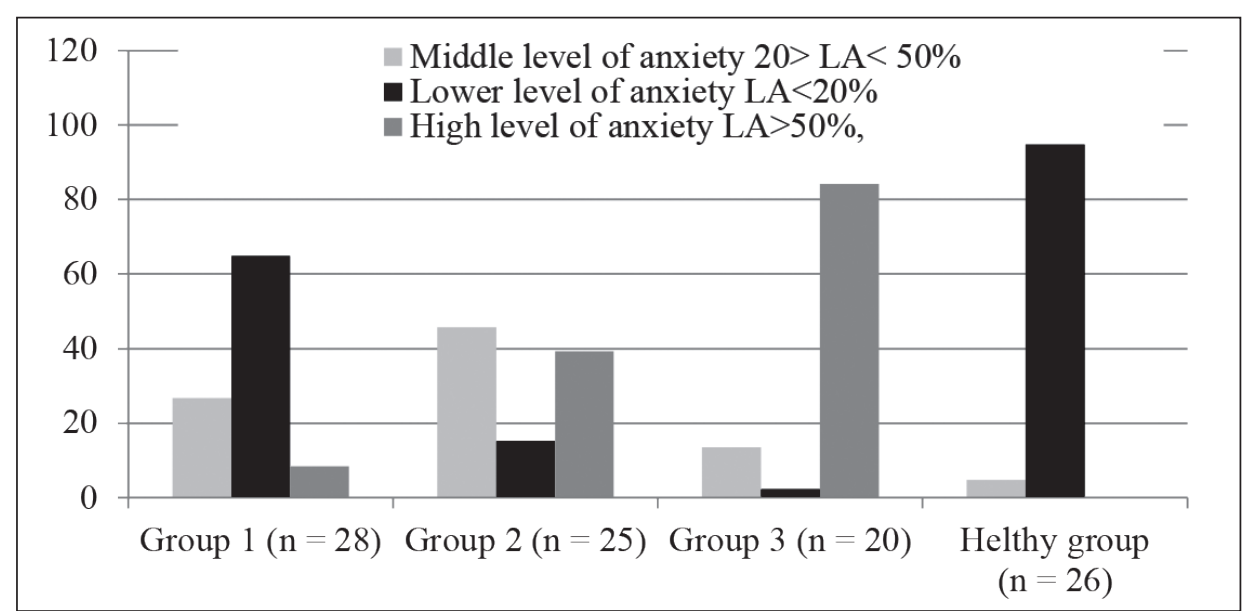

Ca ionized, $\mathrm{mmol} / \mathrm{l}$ (oral fluid)

Ca common, mmol / 1 (oral fluid)

Ca urine, $\mathrm{mg}$ /day (urine)

Ca, mmol / 1 (blood serum)

$\mathrm{Ca}$ (hair)

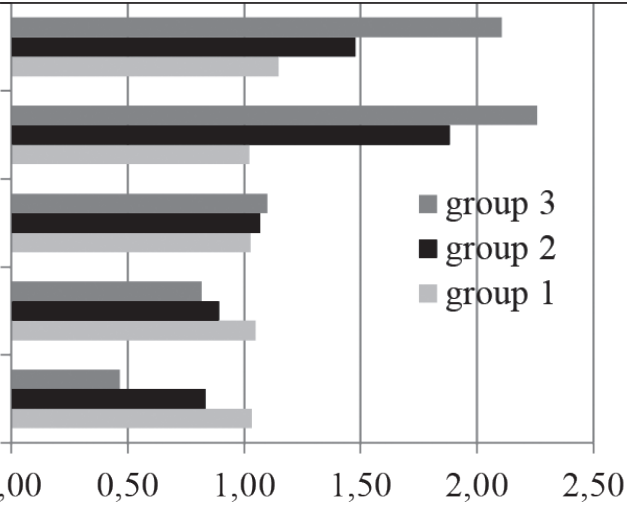

Fig. 1. Childrens anxiety in different groups.

Figure. 2. The relatively proportion of calcium in the body of children to normal level.

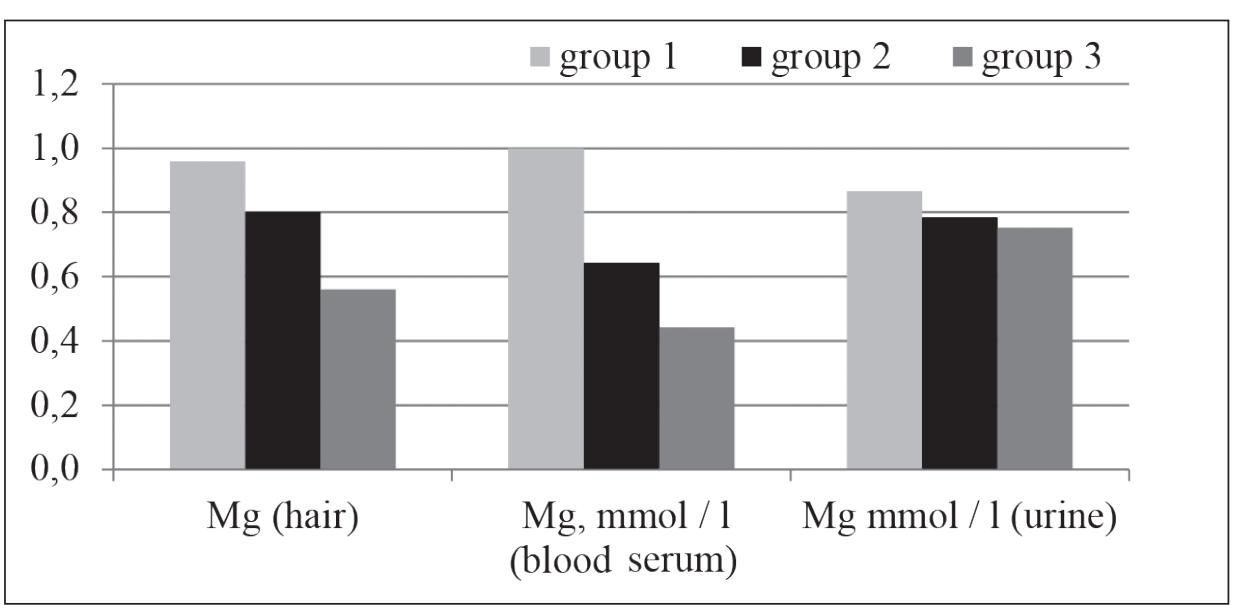

Fig. 3. The relative part of magnesium in children to normal level.

[8], the anxiety level in children according to the test developed by the American psychologists R. Temml, M. Dorca and V. Amen [9]. The indicators of essential elements in the surveyed children in clinical groups were determined as magnesium and calcium levels in the serum, hair, oral fluid, in urinary excretion levels of calcium and magnesium [8].

The statistical analysis of the studied indicators was conducted in the children in three groups; healthy children were adopted as the control group according to which the calculations were made. Statistical processing of the results was performed using the correlation (according to Pearson (r)) and cluster (Euclidian distance method) analyses. All calculations were performed on the PC using licensed "MS Excel 7" software for the "Windows" operating system and the standard software package "STATISTICA" v. 6.0.

\section{RESULTS}

To determine the relationship between caries intensity, stress level, and essential element indices in the surveyed children in the clinical groups, the following indicators were analyzed: anxiety level, caries intensity ( $\mathrm{cf}+\mathrm{CFE}$ index), magnesium and calcium levels in the serum, hair, oral fluid, urinary excretion level of calcium and magnesium. (Tabl.I)

Figure 1 shows the distribution of anxiety in the studied groups of children.

It was found that $95 \%$ of healthy children in the control group had low levels of anxiety; $60 \%$ of children in the first main group had low levels of anxiety and $20 \%$ had medium levels of anxiety. 50\% of the children in the second group had a medium level and $40 \%$ had a high level of anxiety; 

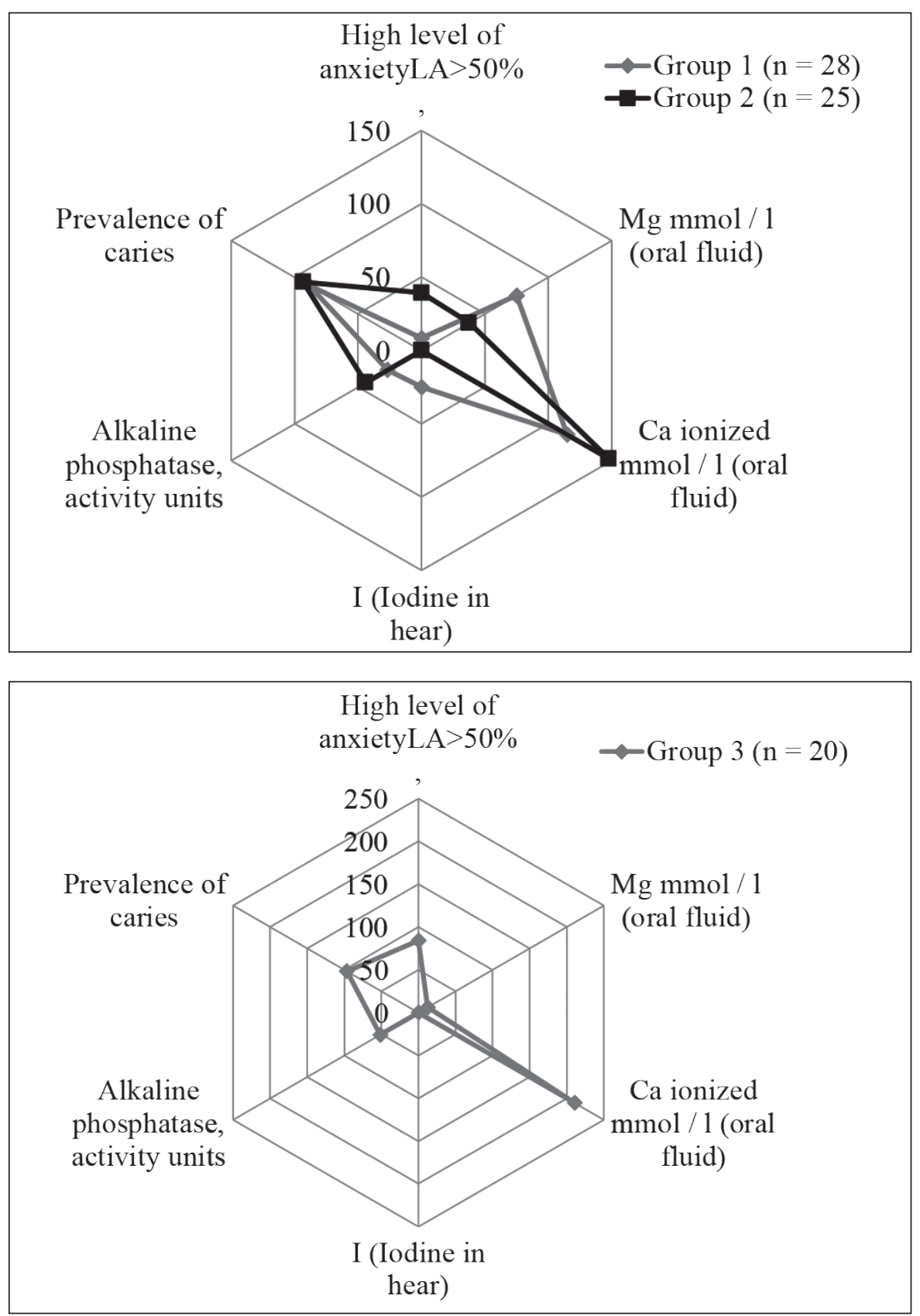

Fig. 4. Indicators of $\mathrm{Mg}$, Ca ion., I, alkaline phosphatase content in two groups of children with high caries prevalence and anxiety level less than $50 \%$ (low and medium levels)

Fig. 5. Indicators of $\mathrm{Mg}$, Ca ion., I, alkaline phosphatase content in third group of children with high caries prevalence and high anxiety level
$80 \%$ of the children in the third group were diagnosed with high levels of anxiety.

Figures 2 and 3 analyze the indicators of calcium and magnesium in the children in the main groups with regard to the minimum norm values.

In the second group, the indicators of ionized and total calcium in the oral fluid are significantly higher than the norm, in the third group, these indicators are twice higher than the norm. The calcium indicator in urine is slightly higher in the second and third groups. Calcium levels in the serum and hair are consistent with the norm in children in the first group, while these indicators in the second and third groups are below the norm. The content of magnesium in the serum in the children of the first group is consistent with the norm, in other patients, magnesium in the hair, serum and urine is understated and ranges from 50 to $75 \%$.
The ratios of caries prevalence, magnesium and calcium ionized content in the oral fluid, iodine in the hair and alkaline phosphatase activity units in two groups of children with low and medium anxiety levels are analyzed below (Figure 4).

Figure 4 shows the correlation between $\mathrm{Mg}, \mathrm{Ca}_{\text {ionn }}$. I, and alkaline phosphatase levels in the children of the first and second clinical groups that do not exhibit high levels of anxiety (i.e., the anxiety rate constitutes less than $50 \%$ ). The prevalence of caries in both groups is high and reaches $100 \%$. Compared to the first group, in the second group of children, a high level of anxiety (medium), an increased rate of calcium ionized and a reliably increased level of alkaline phosphatase in the oral fluid are observed. The increase in the indicator of the latter in the children of the second group compared to the healthy children and the children of the first group is associated with an increase in free calcium in the oral fluid. 


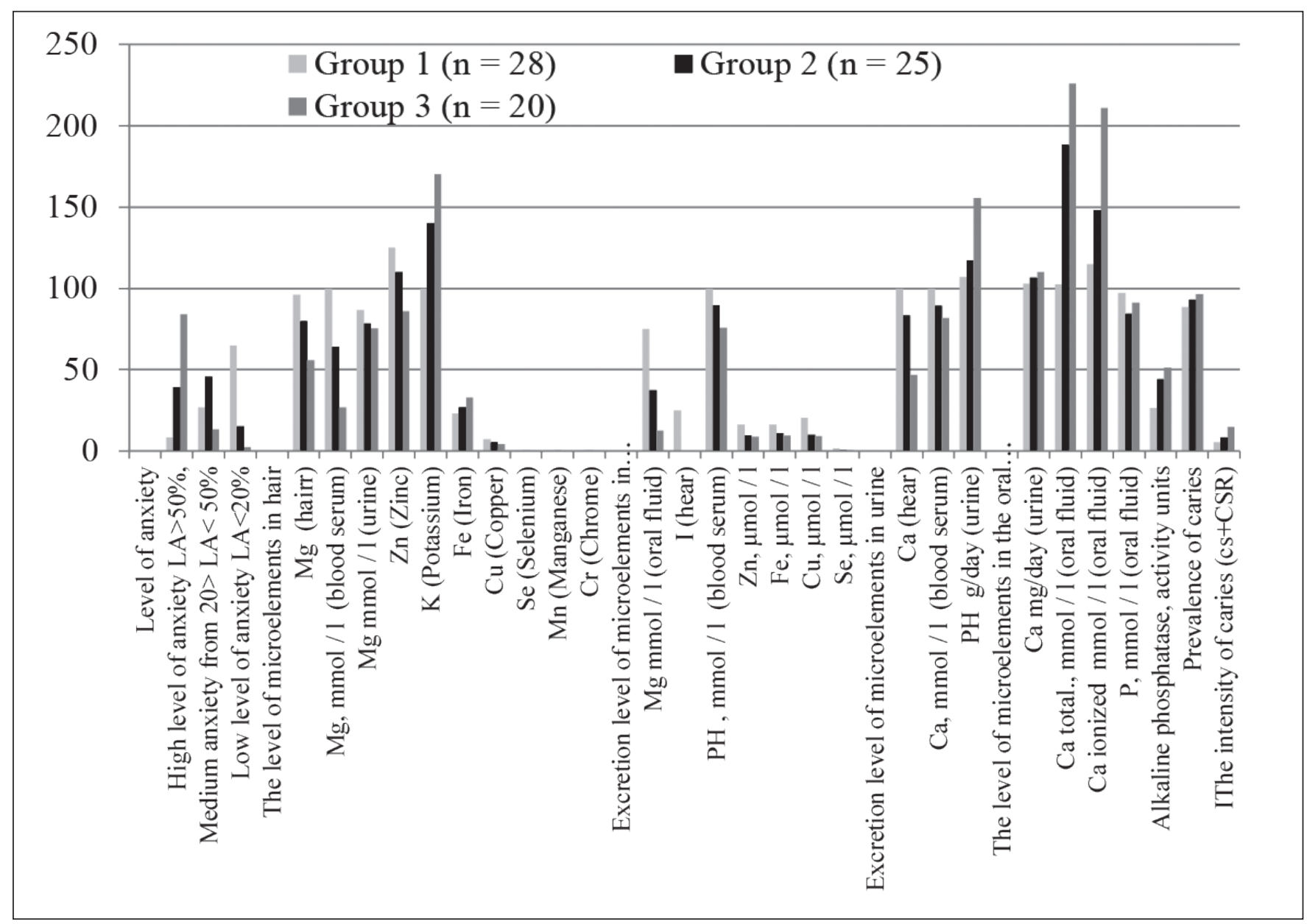

Fig. 6. The main clusters as a factors for the prevalence and intensity of caries

Table II. Correlation dependence of the researched indicators.

\begin{tabular}{|c|c|c|c|c|c|c|c|}
\hline & $\begin{array}{l}\text { High anxiety } \\
\text { level } \mathrm{Al}>50 \% \text {, }\end{array}$ & $\begin{array}{l}\text { Low anxiety } \\
\text { level } A \mid<20 \%\end{array}$ & $\begin{array}{c}\text { Caries } \\
\text { preval. }\end{array}$ & $\begin{array}{c}\text { Alkal. } \\
\text { phosphatase }\end{array}$ & $\begin{array}{l}\text { Ca tot., in } \\
\text { oral fluid }\end{array}$ & $\begin{array}{l}\text { Ca ion., in } \\
\text { oral fluid }\end{array}$ & $\begin{array}{c}P^{H} \text { of urine } \\
\text { g/day }\end{array}$ \\
\hline Low anxiety level $\mathrm{Al}<20 \%$ & $-0,91$ & 1,00 & $-0,90$ & $-0,99$ & $-0,99$ & $-0,94$ & $-0,90$ \\
\hline Zn (Zinc) & $-0,97$ & 0,81 & $-0,57$ & $-0,89$ & $-0,77$ & $-0,75$ & $-0,64$ \\
\hline K (Kalium) & 0,96 & $-0,99$ & 0,89 & 0,99 & 0,98 & 0,96 & 0,91 \\
\hline Fe (Ferrum) & 0,83 & $-0,93$ & 0,99 & 0,88 & 0,97 & 0,99 & 1,00 \\
\hline Cu (Cuprum) & $-0,94$ & 0,99 & $-0,92$ & $-0,97$ & $-0,99$ & $-0,98$ & $-0,94$ \\
\hline Se (Selenium) & $-0,84$ & 0,96 & $-0,99$ & $-0,91$ & $-0,99$ & $-0,99$ & $-0,99$ \\
\hline Mn (Manganese) & $-0,92$ & 0,96 & $-0,94$ & $-0,94$ & $-0,98$ & $-1,00$ & $-0,97$ \\
\hline $\mathrm{Cr}$ (Chrome) & $-0,83$ & 0,95 & $-0,99$ & $-0,90$ & $-0,99$ & $-0,99$ & $-0,99$ \\
\hline Ca (Calcium) in hair & $-0,72$ & 0,87 & $-1,00$ & $-0,80$ & $-0,93$ & $-0,96$ & $-0,99$ \\
\hline$P_{h}$ of urine $g /$ day & 0,80 & $-0,90$ & 0,99 & 0,84 & 0,95 & 0,99 & 1,00 \\
\hline Ca tot., $\mathrm{mmol} / \mathrm{L}$ in oral fluid & 0,89 & $-0,99$ & 0,95 & 0,96 & 1,00 & 0,98 & 0,95 \\
\hline Ca ion., $\mathrm{mmol} / \mathrm{L}$ in oral fluid & 0,88 & $-0,94$ & 0,97 & 0,91 & 0,98 & 1,00 & 0,99 \\
\hline Caries prevalence & 0,74 & $-0,90$ & 1,00 & 0,83 & 0,95 & 0,97 & 0,99 \\
\hline Cariws intensity (cf+CFE) & 1,00 & $-0,89$ & 0,73 & 0,94 & 0,88 & 0,88 & 0,80 \\
\hline
\end{tabular}

The levels of magnesium in the oral fluid and iodine in the hair in the second group (with medium levels of anxiety) are significantly lower, compared to those in the first group and the healthy children, who have a prevailing low level of anxiety. Thus, with an increase in anxiety levels and a decrease in magnesium content, iodine concentration is reduced, which is also observed in the children in the second group.

The correlation of the above-mentioned indicators in the third group of children with high levels of anxiety is analyzed below (Fig. 5). 
In the third group, high anxiety is registered in $80 \%$ and the prevalence of caries is high. The level of calcium ionized in the oral fluid is much higher in comparison with all groups of the studied children, although the level of alkaline phosphatase remained at the samelevel as in the second group. The amount of magnesium is critically low and iodine is not found at all.

In order to determine the dependence of the levels of anxiety, caries prevalence and intensity and the examined elements in the oral fluid, blood, urine and hair, further correlation analysis was carried out. Table 2 shows the results of correlative dependencies. The bold font shows the figures that showed a reliable correlation with $\mathrm{p}<0,05$. The presented list includes only those indicators against which reliable correlation can be observed in more than four cases. (Tabl.II)

Figure 6 presents the most important indicators according to the studies conducted, with the help of which it is reasonable to analyze caries prevalence and intensity, taking into account different levels of anxiety in the children of the three analyzed groups.

\section{DISCUSSION}

Magnesium ions are involved in all life processes that occur in the body without exception, and facilitate their course. Magnesium deficiency inhibits these processes. It is a bioelement that effectively affects everything that happens in cells. Rapid fatigability, difficulty concentrating, sensitivity to changes in the weather, cold, changes in humidity, which causes pain in the teeth, gums, joints, muscles, as well as fears, uncontrolled irritability, unwillingness to do several things at once - these are just some of the symptoms that indicate magnesium deficiency in the body. Therefore, the insufficient level of this element in the children of the second and third groups, indicates a decrease in the resistance of their organisms to negative factors, and may indicate an increased level of anxiety.

In order to determine the dependence of the levels of anxiety, caries prevalence and intensity and the studied elements in the oral fluid, blood, urine and hair, further correlation analysis was carried out.

The conducted correlation analysis found the correlation indicators of magnesium in the body, which are not shown in the table, since they reliably correlate only with each other. $\mathrm{Mg}$ (Magnesium) in hair correlates only significantly with $\mathrm{Mg}, \mathrm{mmol} / \mathrm{L}$ in the serum $(0,98)$, and the latter correlates only with $\mathrm{Mg} \mathrm{mmol} / \mathrm{L}$ in the oral fluid $(0,99)$. Caries intensity correlates only with high levels of anxiety $(1,00)$ and $\mathrm{K}$ $(0,96)$, showing an inverse interdependence with $\mathrm{Zn}(0,97)$.

Iodine manifests significant correlations in four cases: $\mathrm{Zn}(1,0), \mathrm{Fe}(0,98), \mathrm{Cu}(0,99)$, Se $(0,99)$. With $\mathrm{Mg} \mathrm{mmol} / \mathrm{L}$ in the oral fluid it shows a correlation with $p>0,05(0,88)$. Therefore, the amounts of magnesium and iodine in the children's organisms do not show correlatively reliable dependence. This may mean that the amounts of elements in the body are not directly interdependent, and they may be related through certain processes that occur in the body during the transportation, transformation or excretion of these elements.
High anxiety level AI $>50 \%$ gave a significant correlation with $\mathrm{K}(0,96), \mathrm{Zn}(-0,97)$, alkaline phosphatase $(0,96)$ (see Table 2). That is, a high level of anxiety in a child is accompanied by an increase in the amount of potassium and a decrease in the amount of zinc in the body. There is also a correlation of high anxiety at $\mathrm{p}>0,05$ with $\mathrm{Cu}(-0,94)$, Se $(-0,84)$, Mn $(-0,92)$, Cr $(-0,83)$, which may indicate the presence of an indirect connection, for example, due to the quality of intermediate processes that occur in the organisms of the children in the studied groups.

Low anxiety level AI $<20 \%$ with $\mathrm{K}$ correlates in the opposite direction $(-0,99)$, correlates significantly with $\mathrm{Cu}$ $(0,99)$, Se $(0,96), \mathrm{Mn}(0,96), \mathrm{Cr}(0,95)$ in direct relation, as opposed to the correlation of these indicators with high levels of anxiety. A reliable negative correlation of low levels of anxiety was also found with $\mathrm{Ca}, \mathrm{mmol} / \mathrm{L}$ in oral fluid $(-0,99)$ and alkaline phosphatase, activity unit $(-0,99)$. An unreliable correlation was found with $\mathrm{Ca}$ ion., $\mathrm{mmol} / \mathrm{L}$ in the oral fluid $(0,96)$, caries prevalence $(-0,90)$ and caries intensity $(\mathrm{cf}+\mathrm{CFE})(-0,89)$.

Caries prevalence reliably correlates with $\mathrm{Fe}(0,99), \mathrm{pH}$ of urine $\mathrm{g} /$ day $(0,99)$, Ca tot., $\mathrm{mmol} / \mathrm{L}$ in the oral fluid $(0,95), \mathrm{Ca}$ ion., $\mathrm{mmol} / \mathrm{L}$ in the oral fluid (0.97). Negative dependence is observed with Se $(-0,99) \mathrm{Ca}$ in the hair $(-1,0)$.

Thus, the higher the prevalence of tooth decay, the lower the calcium level in the hair and the higher the calcium level in the oral fluid ( $\mathrm{Ca}$ ion. and $\mathrm{Ca}$ in the hair shows $(0,98)$ correlation, $\mathrm{Ca}$ ion. and the prevalence of caries gives $(0,97), \mathrm{Ca}$ tot. and caries prevalence manifest $(0,95)$ positive correlation, at an intensity of caries and $\mathrm{Ca}$ tot. and $\mathrm{Ca}$ ion. the correlation constitutes $(0,88)$, however, at $\mathrm{p}>0,05)$. Ph of urine $\mathrm{g} /$ day also exhibits a dependence with the prevalence of caries $(0,99)$, as well as with calcium $\mathrm{Ca}$ ion. $(0,99)$ and $\mathrm{Ca}$ total $(0,95)$. Accordingly, the dependence of alkaline phosphatase with the content of total and ionized calcium in the oral fluid $(0,96$ and 0,91 correspondingly), is logical. It should also be noted that there is an inverse dependence of alkaline phosphatase and the low level of anxiety in children, that is, the indicator of alkaline phosphatase is low at the low anxiety level, and it grows at the high anxiety level with the probability of correlation $(0,99)$.

Figure 6 shows that from the first to the third groups in the direction of increase proceed the following indicators: the level of anxiety, the amount of calcium in urine per day; the amount of ionized and total calcium in the oral fluid varies significantly between groups; the indicators of alkaline phosphatase, intensity and prevalence of caries are also increasing.

In the direction of decrease from the first group of investigated children to the third one, the following indicators can be seen in the figure: magnesium content in the hair, blood serum, urine and oral fluid. Iodine is absent in the hair in the second and third groups. Calcium indicators in the hair and blood serum also decrease.

The children in the third group have a high level of anxiety (80\%), high intensity of caries (14.8) and significantly reduced magnesium levels relative to normal. And only 
these children have calcium indices slightly deviated from the norm, while in others they are much less than normal.

\section{CONCLUSIONS}

1. In patients of the main groups a direct correlation between the presence of somatic pathology (the coefficient of somatic pathology severity) and the level of anxiety was established, in $80 \%$ of children of the third group (CSPS $\geq 3$ ) the level of anxiety was high, low level of anxiety prevailed in the first group.

2. There is a high prevalence of caries in all groups. Children with high anxiety levels have decreased levels of magnesium and iodine in the body and increased amounts of ionized and total calcium in the oral fluid. Moreover, the alkaline phosphatase index correlates significantly with the prevalence of caries $(0,96)$ and reaches $44-52$ units of activity in the 3rd group of children.

3. The indicators of magnesium content in the studied groups of children show reliable correlation dependencies only among themselves. However, in general, the absolute values of the investigated indicators depend on the level of anxiety and the decrease in magnesium in the body is obvious.

4. The intensity of caries interacts only with a high level of anxiety $(1,00)$, i.e. in children who are in constant stress, the intensity of caries increases.

5. The indicators of total and ionized calcium in the oral fluid and the level of anxiety in the patient may be the first to indicate the prevalence of caries, its intensity, the possible deficiency of all elements in the body that form the clusters.

6. In children of the third group, a high level of anxiety, high intensity of caries and significantly reduced rates of magnesium content relative to the norm are observed; only children in this group have calcium rates unreasonably below normal $(\mathrm{p}>0,05)$.

\section{REFERENCES}

1. Klitinska O.V., Kostenko Y.Y., Gurando V.R. Determination of criteria early caries diagnostics in children of different ethnic groups domiciled in biogeochemical deficiency of fluorine and iodine. Journal of Stomatology. 2016; 70 (1), 1:51-56. D01: 10.5604/01.3001.0010.1778.

2. Kaskova L.F., Artyom's A.V. Prognozyvannya poshirenosti kariesy v istorichnomy aspekty. [Forecasting the breadth of carisu in the historical aspect]. Medical Medicine and Biology. 2012; 4:26-28. (in Ukrainian).

3. Klitinska 0.V. Kompleksne obgryntyvannia diagnostiki, profilaktiki ta poetapnogo likyvannia kariesy y diteh, iaki postihno projivaut v ymovah bioheoximichnogo deficit ftory ta iody [Complex diagnostics, prevention, and preventive care of children, as well as living in the minds of biologic deficiency of fluorine and iodine]. Poltava, 2015; p.150-240 (in Ukrainian).

4. Klitinska 0.V., Vasko A.A., Mukhina Y.A. Exogenus drug prevention of dental caries in primery school children with high caries activity. Intermedical journal. 2016; I (7):10-12.
5. Klitinska 0.V., Kostenko Y.Y., Mukhina Y.A., et al. Efficiency estimation of using phased program of caries prevention in children domiciled in Transcarpathian region. Acta stomatologica Naissi. 2016; 32 (74): 1635-1649. DOI: 10.5937/asnl674635K.

6. Klitinska O.V., Gasyuk N. V, Kostenko Y.Y. et al. Statistical model of caries formation and progression in children of preschool and early school age domiciled in biogeochemical deficiency of fluorine and iodine. Journal of Stomatology.2017;70(6),1:674-678 D0I: 10.5604/01.3001.0010.7725.

7. Klitinska O.V., Vasko A.A., Borodach V.O.et al. Clinical and Laboratory Grounds for the Rational Selection of Filling Material for the Restoration of Deciduous Teeth. Pesquisa Brasileira em Odontopediatria e Clinica Integrada.2018;18(1):e3949 D0l:http://dx.doi.org/10.4034/ PBOCI.2018.181.52 ISSN 1519-0501.

8. Gordov A.V. Trivojnist molodchih shholariv u processi adaptaciy do shkoly: shlahy ta metidy pcixokorekciy. [The thirteenth anniversary of young schools in the process of adaptation to schools: hat and methodical psychocorexia]. Psychologist. 2009;14:1-24. (In Ukrenian)

9. Khomenko L.A. Terapevticheskaya stomatiligia detskogo vozpasta [Therapeutic dentistry of children]. In: Kiselnikova L.P., Smolar N.I. Kiev: Book Plus, 2013, p. 64-85 (In Russian)

This work is a fragment of the research and development the Department of Paediatric Dentistry, State Higher Educational Establishment Uzhhorod National University «Comprehensive justification for providing dental care for children living in the area of biogeochemical deficiency of fluorine and iodine» (№ state registration 0119U101329).

\section{ORCID and contributionship:}

Oksana V. Klitynska - 0000-0001-9969-2833 ${ }^{A, F}$

Andriy V. Stishkovskyy - 0000-0003-2304-958X ${ }^{B}$

Natalia V. Hasiuk - 0000-0002-6798-9090 C

David S. Avetikov - 0000-0002-7055-3589 ${ }^{D}$

Viktoria Z. Ivaskevych - 0000-0002-3701-652X ${ }^{E}$

\section{Conflict of interest:}

The Authors declare no Conflict of interest:

\section{CORRESPONDING AUTHOR}

\section{Oksana V. Klytinska}

Uzhhorod National University (UzhNU),

Narodna Square, 3, 88000, Transcarpathion region, Uzhhorod, Ukraine Tel.: +38(03122)3-33-41.

E-mail: klitinskaoksana@i.ua

Received: 17.01 .2020

Accepted: 05.03.2020

A - Work concept and design, B - Data collection and analysis, C - Responsibility for statistical analysis, $\mathbf{D}$-Writing the article, $\mathbf{E}$-Critical review, $\mathbf{F}$ - Final approval of the article 